\title{
Effects of Bio-physical, Economic and Ecological Policy Drivers on China's Forest Quality transition: Evidence from Panel Analysis
}

\author{
Li Gu${ }^{1}$, Zhiwen Gong ${ }^{1}$, and Weizhong $\mathrm{Li}^{1}$ \\ ${ }^{1}$ Northwest A\&F University
}

May 22, 2020

\begin{abstract}
Similar to the effects of changes in land use and cover, forest transitions have implications for biodiversity and ecosystem functioning. However, forest transition theory ignores ecologically important characteristics, such as forest age, species composition, vertical structure, and all but the most severe levels of degradation. In this study, based on National Forestry Inventories (NFIs) data and socioeconomic panel data covering more than 40 years (1977-2018), we investigate the spatial-temporal dynamics and the spatial determinants of forest quality transition at the province level in China using spatial econometric regression models. Based on our results, we reached the conclusions that follow. (1) Forest area, forest volume, and forest coverage have greatly improved as of 2018, especially for plantations, but uneven forest distribution is an important feature of forest adaptation to the environment. (2) The global Moran's I value is greater than 0.3 , and the forest quality of the provinces has a positive spatial correlation and exhibits obvious spatial clustering characteristics. In particular, the spatial expansion of forest quality has shown an accelerated concentration from 1977 to 2018. (3) The most suitable model for empirical analysis and interpretation was the Spatial Durbin Model (SDM) with fixed effects. The average annual precipitation and the area ratio of the collective forest are positively correlated with forested quality (significance level 1\%). Ultimately, this framework can guide future research, describe actual and potential changes in forest quality associated with forest transitions, and promote management plans that incorporate forest area changes.
\end{abstract}

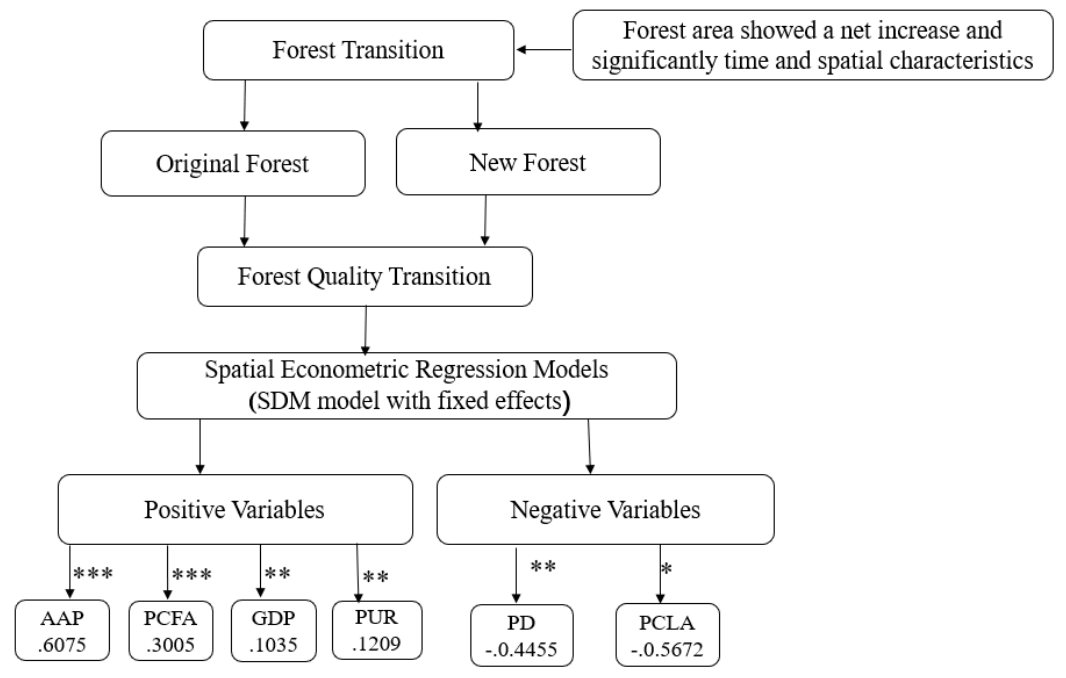

\section{Hosted file}


Man-0522. docx available at https://authorea.com/users/325374/articles/453322-effects-of-biophysical-economic-and-ecological-policy-drivers-on-china-s-forest-quality-transitionevidence-from-panel-analysis

\section{Hosted file}

Tables.docx available at https://authorea.com/users/325374/articles/453322-effects-of-biophysical-economic-and-ecological-policy-drivers-on-china-s-forest-quality-transitionevidence-from-panel-analysis

\section{Hosted file}

Fugures.docx available at https://authorea.com/users/325374/articles/453322-effects-of-biophysical-economic-and-ecological-policy-drivers-on-china-s-forest-quality-transitionevidence-from-panel-analysis 